\title{
CONSTITUTIONALITY OF PERMISSIVE LEGISLATION: THE UNION SHOP PROVISION OF THE RAILWAY LABOR ACT v. STATE "RIGHT TO WORK" LAWS*
}

Section 2(11) of the Railway Labor Act ${ }^{1}$ authorizes the creation of union shop trade agreements between railroad carriers and certified labor organizations. ${ }^{2}$ This 1951 amendment permits making membership in a labor organization a condition of continued employment, notwithstanding state laws to

*Hanson v. Union Pac. R.R., 71 N.W.2d 526 (Neb. 1955), appeal docketed sub nom. Railway Employees' Dep't, AFL v. Hanson, 350 U.S. 910 (1955); Hudson v. Atlantic Coast Line R.R., 242 N.C. 650, 89 S.E.2d 441 (1955), petition for cert. filed, 24 U.S.L. WeEK 3147 (U.S. Nov. 12, 1955) (No. 517).

1. 44 Stat. 577 (1926), as amended, 45 U.S.C. \& 152(11) (1952):

"Eleventh. Notwithstanding any other provisions of this chapter, or of any other statute or law of the United States, or Territory thereof, or of any State, any carrier or carriers as defined in this chapter and a labor organization or labor organizations duly designated and authorized to represent employees in accordance with the requirements of this chapter shall be permitted-

"(a) to make agreements, requiring, as a condition of continued employment, that within sixty days following the beginning of such employment, or the effective date of such agreements, whichever is the later, all employees shall become members of the labor organization representing their craft or class: Provided, That no such agreement shall require such condition of employment with respect to employees to whom membership is not available ufon the same terms and conditions as are generally applicable to any other member or with respect to employees to whom membership was denied or terminated for any reason other than the failure of the employee to tender the periodic dues, initiation fees, and assessments (not including fines and penaities) uniformly required as a condition of acquiring or retaining membership.

"(b) to make agreements providing for the deduction by such carrier or carriers from the wages of its or their employees . . . of any periodic dues, initiation fees, and assessments ... : Provided, That no such agreement shall be effective ... until he [employee] shall have furnished the employer with a written assignment to the labor organization of such membership dues, initiation fees, and assessments. . . "

2. The Act also authorizes a checkoff by the employer of union dues, fees and assessments, with the consent of the employee. Ibid.

The following are definitions of terms pertinent to $\$ 2(11)$ of the RLA :

(a) union security-various agreements between employer and union, assuring the union either stable membership, or stable income, or both.

(b) union shop-an agreement between employer and union, allowing the employer to hire nonunion employees on condition that they become members of the union within a specified time, and thereafter maintain membership in good standing in order to retain their jobs.

(c) checkoff-a payroll deduction plan for union dues, fees and assessments.

See, generally, Murphy, The "Right to Work" Statute, 26 Mrss. L.J. 39-41 (1954); Rosenthal, The National Labor Relations Act and Compulsory Unionism, 1954 Wis. L. REv. 53,55 n.4. 
the contrary. ${ }^{3}$ Section $2(11)$ constitutes a complete reversal of the 1934 amendment to the Act, which prohibited a union shop. ${ }^{4}$ It differs from the union shop amendment to the Taft-Hartley Act, ${ }^{5}$ which does not invalidate state laws barring union security agreements, "the so-called "right to work" laws. ${ }^{7}$ The union shop amendment to the RLA has provoked much controversy concerning two problems: (1) Is the constitutionality of section 2(11) in issue when a dispute arises over the enforcement of a union shop trade agreement? (2) If so, is section $2(11)$ constitutional?

In two recent cases involving similar facts, state courts have reached opposite conclusions on both questions. ${ }^{8}$ In Hanson $v$. Union Pacific R.R. ${ }^{8}$ and Hudson v. Atlantic Coast Line R.R., ${ }^{10}$ the carriers entered, pursuant to section 2(11),

3. Contracts requiring actual membership in a union, as distinguished from mere tender of dues, fees and assessments, are authorized by $\$ 2(11)$ of the RLA. Hearings Before the Subcommittee on the Study to Amend the Railway Labor Act of the Senate Committee on Labor and Public Welfare, 81st Cong., 2d Sess. 23 (1950) (hereinafter cited as Hearings) ; Pan American Airways, Inc., 20 Lab. Arb. 312 (1953); Note, 52 MicH. L. REv. 619 (1954); cf. Cogen, Is Joining the Union Required in the Taft-Hartley Union Shop?, 5 LAB. L.J. 659 (1954). But see Toner, The Union Shop Under Taft-Hartley, 5 LAB. L.J. 552 (1954). See text at note 52 infra.

4. 64 STAт. 1238 (1951), 45 U.S.C. $\$ 152$ (11) (d) (1952), amending 48 STAT. 1186 (1934). The legislative history of this series of union security amendments to the RLA is summarized in H.R. REp. No. 2811, 81st Cong., 2d Sess. 3-4 (1950).

5. 61 StaT. 140-41 (1947), 29 U.S.C. $\$ 158$ (a) (3) (1952), amending 49 Stat. 452 (1935).

6. 49 STAT. 457 (1935), as amended, 29 U.S.C. $\$ 164$ (1952).

7. Seventeen states have statutory or constitutional provisions outlawing the union shop. See Note, $50 \mathrm{Nw}$. U.L. REv. 773, 774 n.10 (1956). In the absence of federal law to the contrary, state right to work laws have been upheld. Lincoln Federal Labor Union v. Northwestern Co., 335 U.S. 525 (1949) ; AFL v. American Sash \& Door Co., 335 U.S. 538 (1949).

However, the above cases concerned industrial unions, not railroad unions. It might well be argued that states lack concurrent jurisdiction to regulate labor relations in the railroad industry, due to the national scope of the activity. See Cooley v. Port Wardens, 53 U.S. (12 How.) 299 (1981). But the presumption is against this interpretation. See Lincoln Federal Labor Union v. Northwestern Co., supra; Southern Pac. Co. v. Arizona cx rel. Sullivan, 325 U.S. 761 (1945).

8. The following cases have held that the constitutionality of $\S 2(11)$ of the RLA was not properly in issue: Otten v. Baltimore \& O.R.R., 205 F.2d 58 (2d Cir. 1953); Wicks v. Southern Pac. Co., 121 F. Supp. 454 (S.D. Cal. 1954); Hudson v. Atlantic Coast Line R.R., 242 N.C. 650,89 S.E.2d 441 (1955), petition for cert. filed, 24 U.S.L. WEEK 3147 (U.S. Nov. 12, 1955) (No. 517) ; International Ass'n of Machinists v. Sandsberry, 277 S.W.2d 776 (Tex. Civ. App. 1954).

The following cases have upheld the constitutionality of $\S 2(11)$ of the RLA: In re Florida East Coast Ry., 32 L.R.R.M. 2533 (S.D. Fla. 1953) ; Moore v. Chesapeake \& O. Ky., 34 L.R.R.M. 2666 (Hustings Ct., Richmond, Va. 1954). The single case holding the statute unconstitutional is Hanson v. Union Pac. R.R., 71 N.W.2d 526 (Neb. 1955), appeal docketed sub nom. Railway Employees' Dep't, AFL v. Hanson, 350 U.S. 910 (1955).

9. 71 N.W.2d 526 (Neb. 1955), appeal docketed sub nom. Railway Employees' Dep't, AFL v. Hanson, 350 U.S. 910 (1955).

10. 242 N.C. 650 , 89 S.E.2d 441 (1955), petition for cert. filed, 24 U.S.L. WeEK 3147 (U.S. Nov. 12, 1955) (No. 517). 
into union shop trade agreements with the unions representing their employees. A number of the nonoperating employees, threatened with discharge for failure to comply with the agreements, brought suits to enjoin their enforcement, alleging that such agreements violated the applicable state right to work laws and the United States Constitution. ${ }^{11}$ In Hanson the Nebraska Supreme Court held that section 2(11) constituted government action in authorizing a union shop. The court reasoned that since the federal statute purported to invalidate the state right to work law, a union shop "depended" on the federal statute in Nebraska. ${ }^{12}$ It held that section 2(11) violated the Fifth Amendment in that union membership had no reasonable relation to equitable distribution of collective bargaining costs, and that union dues, fees and assessments were not a reasonable measure of such costs. ${ }^{13}$ In Hudson the Supreme Court of North Carolina held that section 2(11) did not constitute government action, since it was only permissive, not mandatory. ${ }^{14}$ Therefore, the court denied the existence of any constitutional question. But the court stated by way of dictum that even if the Constitution were applicable, it would not invalidate section $2(11) .{ }^{25}$

The Hanson and Hudson cases present to the Supreme Court one aspect of the perplexing question-when may acts of private groups be held to constitutional standards? At first glance, the answer to this question is "never," and the United States Supreme Court has established precedent for this conclusion. ${ }^{16}$ But in fact, that Court and many others have subjected some

11. U.S. Const. amend. I, V; Neb. Const. art. XV, § 13 ; Neb. Rev. Stat. $\$ 48-217$ (1952) ; N.C. CoDE $\$ \$ 95-78-95-84$ (1949). See note 7 supra.

The nonoperating employees were not as concerned with the requirement that all employees must join a union as they were with the provision of $\$ 2(11)$ of the RLA authorizing an agreement requiring employees classified as nonoperating to transfer from one union to another when a new job requires a change in the employees' craft or class. Such a transfer is not required of operating employees under the Act. But in both Hanson v. Union Pac. R.R., 71 N.W.2d 526, 544 (Neb. 1955), and Hudson v. Atlantic Coast Line R.R., 242 N.C. 650,89 S.E.2d 441, 452 (1955), the courts held that there was no unreasonable classification involved. A nonoperating employee is one engaged in wo:k included in a craft or class listed in the RLA, 44 STAT. 578 (1926), as amended, 45 U...$\$ \$ 153(\mathrm{~h})$ (2), (3), (4) (1952).

12. Hanson v. Union Pac. R.R., supra note 11, at 546-47. The court's theory of government action is specious. It states the effect of the statute, not the reason why the statute constitutes government action. A union shop "depends" on $\$ 2(11)$ of the RLA not only in right to work states, but in all states, since the 1934 amendment to the RLA prohibited a union shop in all states. See note 4 supra. A possible rationale for finding that $\$ 2(11)$ constitutes government action in right to work states is suggested in the text at note 32 infra. The "dependence" rationale states no more than the principle that federal laws are supreme over state laws. U.S. Const. art. VI; Garner v. Teamsters Union, AFL, 346 U.S. 485, $492-501$ (1953) ; Napier v. Atlantic Coast Line R.R., 272 U.S. 581, 613 (1926).

13. Hanson v. Union Pac. R.R., 71 N.W.2d 526, 547 (Neb. 1955).

14. Hudson v. Atlantic Coast Line R.R., 242 N.C. 650, 89 S.E.2d 441, 452 (1955).

15. Id., 89 S.E.2d at $452-54$.

16. It is accepted doctrine that the Constitution protects individuals only against government or public action, not against acts of private persons. Corrigan v. Buckley, 271 U.S. 323 (1926); Civil Rights Cases, 109 U.S. 3 (1884). 
private action to constitutional limitations on various grounds. One method, prevalent in state courts, is to hold a contract void as contrary to public policy, finding such policy in constitutional limitations. ${ }^{17}$ Less frequently, courts have held that there would be unconstitutional state action if a court were to enforce a contract abridging constitutional rights. ${ }^{18}$ But the contract approach is not consistently applied. ${ }^{19}$ Another approach is to view the private party itself as a governmental or quasi-governmental entity for constitutional purposes. This view, as applied to labor unions, rests on the premise that since the union enacts economic legislation and performs administrative and judicial functions within its organization, it is an independent governmental body and as such subject to constitutional limitations. ${ }^{20}$ This theory has not been well received

17. E.g., Dooley v. Lehigh Valley R.R., 130 N.J. Eq. 75, 81, 21 A.2d 334, 338 (Ch. 1941) ; Cameron v. International Stage Employees, 118 N.J. Eq. 11, 176 At1. 692 (Ch. 1935). See Hale, Rights Under the Fourteenth and Fifteenth Amendments Against Injuries Inficted by Prizate Indiziduals, 6 LAw. GuILd Rev. 627 (1946).

18. E.g., Barrows v. Jackson, 346 U.S. 249 (1953) ; Hurd v. Hodge, 334 U.S. 24 (1948); Shelley v. Kraemer, 334 U.S. 1 (1948).

19. E.g., Steele v. Louisville \& N.R.R., 245 Ala. 113, 16 So. $2 d$ 416, rev'd, 323 U.S. 192 (1944) ; Meade v. Dennistone, 173 Md. 295, 302, 196 Atl. 330, 333 (1938) ; Note, 48 Colum. L. Rev. 1241 (1948). See Wollett \& Wellington, Federalism and Brcach of the Labor Agrecment, 7 Stan. L. Rev. 445 (1955), as to whether a state court has jurisdiction over a labor dispute, either as to substantive or adjective law.

Some writers have discouraged judicial intervention in labor disputes. Shulman, Reason, Contract, and Law in Labor Relations, 68 Harv. L. Rev. 999 (1955); Gregory, The Collective Bargaining Agrcement: Its Nature and Scope, 29 WAS\#. U.L.Q. 3 (1949); Williams, The Political Liberties of Labor Union Members, 32 Texas L. Rev. 826 (1954).

One of the major inadequacies of the common law approach to the protection of individual rights relative to employment is that most courts have required that a person be a union member or an employee before bringing suit to enjoin a discriminatory contract or action. E.g., Murphy v. Higgins, 12 N.Y.S.2d 913 (Sup. Ct. 1939). Two states have not followed this theory, however. Williams v. International Brotherhood of Boilermakers, $27 \mathrm{Cal}$. 2d 586, 165 P.2d 903 (1946) ; Carroll v. Local 269, International Brotherhood of Electrical Workers, 133 N.J. Eq. 144, 147, 31 A.2d 223, 225 (Ch. 1943).

20. See, generally, Merriam, Public and Private Government (1944); Jaffe, Law Making by Private Grouts, 51 Harv. L. Rev. 201 (1937); Malick, Toward a New Constitutional Status far Labor Unions: A Proposal, 21 Rocky MT. L. Rev. 260 (1949); Summers, Legal Limitations on Union Discipline, 64 Harv. L. Rev. 1049 (1951); Wirtz, Government by Private Grouts, 13 LA. L. Rev. 440 (1953). See James v. Marinship Corp., 25 Cal. 2d 721, 740, 155 P.2d 329, 340 (1944). See also Marsh v. Alabama, 326 U.S. 501 (1940) (it is not clear whether the Court categorized the town, owned by Gulf Shipbuilding Corp., as an independent government, or as an agent of government).

Unions are said to be legislative for the following reasons: (1) As exclusive bargaining representatives for a craft, a union determines the rights of not only union, but nonunion employees, see Steele v. Louisville \& N.R.R., 323 U.S. 192, 200-02 (1944); Wallace Corp. v. NLRB, 323 U.S. 248, 255-56 (1944); (2) Neither union nor nonunion employees are immediate parties to the agreements between employer and union; and (3) Such trade agreements are given legal priority over the individual contract of employee with employer, see J. I. Case Co. v. NLRB, 321 U.S. 332, 335 (1944) (trade agreement compared to a government regulation to which individual contracts must conform); Lenhoff, The Present Status of Collective Contracts in the American Legal System, 39 Micr. L. Rev. 1109, 1137 (1941). 
by the courts. ${ }^{21}$ Where private action has been authorized by statute, some courts have applied constitutional limitations to persons exercising such authority by classifying them as government agents. ${ }^{22}$ This last analysis creates difficulty in determining just when an agency relationship exists, and courts have been reluctant to adopt it. ${ }^{23}$

But while it may be possible under some circumstances to apply constitutional limitations directly to "private" persons or groups, ${ }^{24}$ it was unnecessary to do so in the Hanson and Hudson cases. For the question in these cases was not whether the Constitution directly restricts private action, but whether it restricts the power of Congress to enact permissive legislation. Despite incautious dicta by several courts to the contrary, ${ }^{25}$ this question must be answered unqualifiedly in the affirmative. Certainly no rationale is apparent by which Congress could validly enact legislation without reference to constitutional grants of power and limitations on power. If a federal statute will operate to deprive individuals or groups of rights secured by the Constitution, it is invalid. And this conclusion should follow without regard to whether the deprivation is physically accomplished by agents of government or by private individuals using the congressional enactment as a shield. ${ }^{26}$ The enactment of the statute authorizing invasion of private rights is the "government action" upon which the Constitution operates.

21. See, e.g., Dorsey v. Stuyvesant Town Corp., 299 N.Y. 512, 87 N.E.2d 541 (19.9), cert. denied, 339 U.S. 981 (1950).

22. Betts v. Easley, 161. Kan. 459, 169 P.2d 831 (1946) (labor union held a government agency). The following cases in dicta have compared a labor union to a government agency: Steele v. Louisville \& N.R.R., 323 U.S. 192, 198-99 (1944); Rolax v. Atlantic Coast Line R.R., 186 F.2d 473, 478 (4th Cir. 1951). But see American Communications Ass'n v. Douds, 339 U.S. 382, 402 (1950) (dictum); Courant v. International Photographers, 176 F.2d 1000, 1003 (9th Cir. 1949).

Courts have held other private persons and groups subject to constitutional limitations by using an agency relationship. Marsh v. Alabama, 326 U.S. 501 (1946) ; Smith v. Allwright, 321 U.S. 649, 663, 666 (1944) ; Nixon v. Condon, 286 U.S. 73, 88 (1932); Kerr v. Enoch Pratt Free Library, 49 F.2d 212 (4th Cir. 1945).

For a discussion of whether a labor union is a government agency, see Hearings, supra note 3, at 161; Hale, supra note 17; Notes, 61 HARv. L. REv. 344 (1948), 56 YALE L.J. 731 (1947), 58 HARV. L. Rev. 448, 451 (1945).

23. See cases cited note 22 supra.

24. See notes 17-18, 20, 22 supra.

25. Two state courts have stated that it is impossible to consider the constitutionality of $\S 2(11)$ of the RLA since it is "permissive" in nature and not "mandatory," and consequently it does not constitute affirmative government action to which the Constitution is applicable. Hudson v. Atiantic Coast Line R.R., 242 N.C. 650, 89 S.E.2d 441, 452 (1955); International Ass'n of Machinists v. Sandsberry, 277 S.W.2d 776 (Tex. Civ. App. 1954). Both cases relied on Otten v. Baltimore \& O.R.R., 205 F.2d 58, 60 (2d Cir. 1953), which did state that the constitutionality of $\S 2(11)$ could not be determined in New York. But the facts in Otten differ from the above two cases in that New York does not have a state right to work law. Since in addition a union shop was permissible in New York at common law, $\S 2(11)$, in authorizing a union shop, did not deprive Otten of any right which he otherwise would have possessed. See note 29 infra and accompanying text.

26. See text at notes 16,22 supra. 
Although the Constitution invariably "applies" to permissive legislation, it does not necessarily follow that a court must pass upon the constitutionality of a permissive statute whenever it is asked to do so. The rule of avoiding constitutional questions whenever possible, a principle which is itself of nearly constitutional force, may require disposition of the case without reaching constitutional issues. ${ }^{27}$ Thus in Otten $v$. Baltimore \& O.R.R., ${ }^{28}$ cited by the court in Hudson for the proposition that "merely permissive" legislation can raise no constitutional issues, the Second Circuit refused to pass upon the constitutionality of section 2(11) of the RLA. But Otten is distinguishable in one crucial respect: unlike $H u d s o n$, it arose in a state where neither statutory nor common law entitled the plaintiff to relief against a union shop. ${ }^{29}$ Since the plaintiff had failed to state a claim on which relief could be granted, and since section 2 (11) could be raised only by way of defense, the court dismissed plaintiff's claim on the merits, and held that it was unnecessary to reach the question whether $2(11)$ was constitutional. ${ }^{30}$ Since a holding that $2(11)$ was

27. See Joint Anti-Fascist Refugee Comm. v. McGrath, 341 U.S. 123, 136 (1951); United States v. Lovett, 328 U.S. 303, 320 (1946) ; Ashwander v. Tennessee Valley Authority, 297 U.S. 288, 341 (1936) (concurring opinion of Brandeis, J.).

28. 205 F.2d 58 (2d Cir. 1953).

29. Otten v. Baltimore \& O.R.R., 205 F.2d 58 (2d Cir. 1953), was decided under New York law where a union shop is valid at common law. Williams v. Quill, 277 N.Y. 1,12 N.E.2d 547 (1938). But Hudson v. Atlantic Coast Line R.R., 242 N.C. 650 , 89 S.E.2d 441. (1955), arose in North Carolina where a right to work law existed. See note 11 supra.

On facts similar to Otten v. Baltimore \& O.R.R., supra, the court in Wicks v. Southern Pac. Co., 121 F. Supp. 454 (S.D. Cal. 1954) held that $\$ 2(11)$ presented no constitutional issue.

The statute may determine the rights of a person if it deprives him of a remedy which he formerly had against the authorized action. See Steele v. Louisville \& N.R.R., 323 U.S. 192,200 (1944). The former remedy may have been based on a statute such as the right to work law in Nebraska, supra note 11, or on the common law as suggested by Judge Learned Hand in Otten v. Baltimore \& O.R.R., supra. See Truax v. Corrigan, 257 U.S. 312, 329-30 (1921), where Chief Justice Taft stated:

"It is true that no one has a vested right in any particular rule of the common law, but it is also true that the legislative power of the state can only be exerted in subordination to the fundamental principles of right and justice which the guaranty of due process in the Fourteenth Amendment is intended to preserve, and that a purely arbitrary and capricious exercise of that power whereby a wrongful and highly injurious invasion of property rights, as here, is practically sanctioned and the owner stripped of all real remedy, is wholly at variance with those principles."

If state right to work laws are unconstitutional due to absence of concurrent jurisdiction to control interstate railroad labor relations, such laws might be void $a b$ initio. Thus no rights of the employee would be abrogated by $\$ 2(11)$ of the RLA. This rationale is not, however, likely to be adopted. See note 7 supra.

30. In Otten v. Baltimore \& O.R.R., supra note 29 , Otten requested both a three-Judge court and an injunction against enforcement of a union shop contract. Under the Federa1 Judiciary Act, only a three-Judge court can declare a federal statute invalid. 28 U.S.C. $\$ 2282$ (1952). Thus, only because Otten requested such a court did the court here consider whether a proper constitutional question was presented. Otherwise, the court would have dismissed the petition for failure to state a claim without discussing the constitu- 
unconstitutional would not have entitled Otten to relief, it was unnecessary to determine whether such a holding was warranted on the merits. In Hanson and $H u d s o n$, on the other hand, the plaintiffs stated valid claims under state right to work laws, and it became necessary to determine the validity of section $2(11)$ as a defense. ${ }^{31}$ The court in Otten stated explicitly that a constitutional question might well be presented if, as was the case in Hanson and Hudson, the statutory or common law of the state would entitle the plaintiff to an injunction against enforcement of union shop contracts but for 2(11).3:

The suggested rationale creates the seeming paradox that a permissive statute like the RLA may be subject to constitutional attack in some jurisdictions but not in others. This paradox is, however, only a variant of the situation which obtains with respect to all legislation by virtue of the constitutional provision restricting federal judicial power to "cases and controversies." ${ }^{33}$ Thus a patently unconstitutional statute may go unchallenged for years if no litigant appears who has been injured by it, and who has standing to litigate. ${ }^{34}$ In the case of a permissive statute, which can ordinarily be raised only by way of defense, ${ }^{35}$ a plaintiff clearly must state a claim for relief before he can challenge the validity of the defense. No justiciable issue is presented if the permissive statute "permits" action which is permissible in any event. The "affirmative government action" which has been sought by courts in permissive statute cases is thus an essential prerequisite to a constitutional decision. ${ }^{3 n}$ And

tional issue. For under no law, either federal or state, did the plaintiff possess a valid claim for relief against the imposition of the union shop, since a union shop is permissible at common law in New York, and such law was applicable to Otten. In short, Otten had no standing to litigate the constitutionality of $\$ 2(11)$, since the statute did not injure him by depriving him of the right to resist a union shop which the statute authorized. A plaintiff is not permitted to base his action solely on the invalidity of the defense. Sec HaLE, Freedom Through Law 327-35 (1952).

31. See note 11 supra.

32. Otten v. Baltimore \& O.R.R., 205 F.2d 58, 60 (2d Cir. 1953).

33. U.S. Const. art. III, $\S 2$, cl. 1; Muskrat v. United States, 219 U.S. 346 (1911).

34. Doremus v. Board of Education, 342 U.S. 429 (1952) ; Ashwander v. Tennessee Valley Authority, 297 U.S. 288 (1936); Massachusetts v. Mellon, 262 U.S. 447 (1923).

35. Since a "permissive" statute does not make mandatory any particular act, a plaintiff could not use the statute to force the defendant to do a particular act. Therefore, the merits of the statute would be placed in issue validly only by a defendant who seeks to justify his actions under the authority granted by the statute.

36. On at least one occasion the Supreme Court has chosen to rule on the constitutionality of a permissive statute when in fact no constitutional issue was presented. In Senn v. Tile Layers Protective Union, 301 U.S. 468, 476 (1937), a Wisconsin statute authorized a form of picketing which the Court apparently conceded was permitted at common law. The statute deprived no one of any right previously enjoyed, since if the statute were held invalid, the authorized activity still could continue. But the Court decided the constitutionality of the statute, contending that its validity was properly challenged under the Fourteenth Amendment since the state courts had based their rulings on the authorizing statute.

In several more recent dicta the Court has apparently followed the seemingly errontous Sem rationale for determining when constitutional questions posed by a permissive statute 
such affirmative action is present only when the statute would, if upheld, defeat a valid claim to relief against conduct by private parties which the statute authorizes. Thus, in Hanson and Hudson section 2(11) purported to invalidate state right to work laws and thereby to defeat plaintiffs' claims to relief against enforcement of union shop contracts. This affirmative action is not, however, required to subject permissive legislation to constitutional standards; it is a requisite only of a judicial decision on the constitutionality of such legislation, since without it, the rule of avoiding unnecessary constitutional decisions would require disposition of the case on non-constitutional grounds. ${ }^{37}$

A problem of obvious importance in any controversy involving permissive legislation is to determine precisely what the statute in question authorizes Thus a statute merely repealing a prior statutory prohibition authorizes nothing, and can raise no constitutional questions. It may be that such a statute is not subject to constitutional restraints at all, since it merely withdraws governmental power rather than asserts it. ${ }^{38}$ But in any event such a statute could never present a justiciable issue: since the statute would leave a court at liberty to grant or deny relief on common law grounds against the "permitted" conduct, no plaintiff could ever complain that the statute exercised a necessarily determinative effect on his claim. ${ }^{39}$ Similarly, a statute may authorize a defendant to function as an entity or in a particular capacity, as statutory corporate charters do, for example, yet not authorize the particular conduct

must be answered. In Steele v. Louisville \& N.R.R., 323 U.S. 192, 198-99 (1944), where a statute authorized a union to act as exclusive bargaining representative for a particular craft, the Court stated that had the statute not imposed an implied duty to represent all craft members fairly, grave consitutional issues would arise. But before a constitutional issue would arise, there must necessarily be a determination that the complainant has a right under the statutory or common law of his state to enjoin enforcement of the authorized conduct but for the authorizing statute. Since Steele's rights under state law were not in issue in the court below, the Court presumably should have remanded the case in order that such rights might be determined. Unless the complainant has been deprived of a remedy by the permissive statute, he has not sustained any injury and has no standing to litigate the constitutionality of the permissive statute. See note 30 supra. But sec note 37 infra. The Steele dictum may, however, be justifiable if it referred to the constitutional questions discussed in note 40 infra and accompanying text, rather than to any constitutional questions posed by the statute itself.

37. See note 27 supra. But the dictum in Steele v. Louisville \& N.R.R., supra note 36, may state a wise policy in that even though a "permissive" federal statute may not conflict with any state law, it encourages the type of action authorized by the statute, and might be said to influence a state legislature not to change its own laws, or influence a state court not to change the common law of the state. But it is questionable that this approach indicates an injury to a plaintiff sufficiently definite to invoke the jurisdiction of a court to consider the constitutionality of the federal statute. See Massachusetts v. Mellon, 262 U.S. 447 (1923). But see Ashwander v. Tennessee Valley Authority, 297 U.S. 288 (1936).

38. It has been suggested that if a state were to repeal its own law for the purpose of encouraging discriminatory action and depriving a person of a remedy against it, such a repeal would be unconstitutional. See Hale, supra note 17 , at $636-37$; Smith v. Allwright, 321 U.S. 649, 664 (1944).

39. See text at note 32 supra. 
(perhaps carrying out a union shop contract) of which the plaintiff complains. In such a case the plaintiff may argue that the defendant is directly subject to the Constitution as a quasi-governmental entity or as a government agent; 40 or that a statute creating an entity with powers so sweeping as to include the offending conduct is void as an unconstitutional delegation of governmental power. ${ }^{41} \mathrm{He}$ plainly may not, however, utilize the rationale previously outlined for "permissive" statutes unless the conduct of which he complains is expressly permitted by the statute. He may, in short, challenge the constitutionality of the statute only to the extent that it necessarily constitutes a defense against his claim. ${ }^{42}$

Although the court in Hanson was correct in holding that it was obligated to decide the constitutional question presented, its conclusion that section 2(11) was unconstitutional seems erroneous. The court conceded that federal regulation of distribution of collective bargaining costs in the railroad industry would be a reasonable exercise of the commerce power, ${ }^{43}$ but held that section $2(11)$ 's method of distributing such costs denied due process of law in two respects. It held first that compulsory membership in a union is not reasonably related to distribution of collective bargaining costs, and second, that union dues, fees and assessments are not a reasonable measure of these costs. But compulsory membership does have a reasonable relation to distribution of bargaining costs, since membership is a convenient and efficient means of collecting such costs. ${ }^{44}$ And union dues, fees and assessments are a reasonably

40. See notes 20, 22 supra; cf. Crossen v. Duffy, 90 Ohio App. 252, 269-72, 103 N.E. 2d 769, 777-78 (1951).

41. Congress cannot delegate its power to legislate, except when such delegation is limited by definite standards enabling Congress, the courts and the people to judge whether the agency exercising the delegated power has exceeded the authority delegated. Yakus v. United States, 321 U.S. 414 (1944) ; A. L. A. Schechter Poultry Corp. v. United States, 295 U.S. 495 (1935). In dictum, the Supreme Court in Steele v. Louisville \& N.R.R., 323 U.S. 192, 198 (1944), indicated that were the power granted by the RLA to a union-to represent exclusively a particular craft-not accompanied by an implied duty to represent all members of that craft fairly, grave constitutional questions would arise. The Court seemed to indicate that it would base such a constitutional issue on that delegation of power. See HAlE, op. cit. supra note 30, at 348-66. But see note 36 supra, for other possible bases for the constitutional issues which the Court thought might arise. As to whether a particular power is legislative in nature, see note 20 supra.

42. See text at notes 32,34 supra.

43. See NLRB v. Jones \& Laughlin Steel Corp., 301 U.S. 1, 31, 37 (1936); Virginian Ry. v. System Federation No. 40, 300 U.S. 515, 553 (1936) ; Texas \& N.O.R.R. v. Railw2y Clerks, 281 U.S. 548,570 (1929).

44. The guaranty of due process demands only that a law shall not be unreasonable, arbitrary or capricious, and that the means selected shall have a real and substantial relation to the object sought to be obtained. Nebbia v. New York, 291 U.S. 502, 525 (1934). See Note, 30 Colum. L. Rev. 360 (1930).

Since most railroad employees were union members prior to $\S 2(11)$, a requirement that the small minority of employees join the majority of employees is a convenient and ready solution to the problem of distributing bargaining costs. Hearings, supra note 3 , at 4, 114; National Mediation Board, 19th Ann. Rep. 9-10 (1953) ; H.R. Rep. No. 2811, 
accurate measure of bargaining costs. They are used to support unionism generally, which is essential to continuation of the bargaining process. ${ }^{45}$ This is so even if such funds are used for political purposes, for political activity is a legitimate if not indispensable means of advancing the cause of organized labor. ${ }^{48}$

The court in Hanson also suggested that compulsory membership infringes on an employee's freedom of assembly and right to work protected by the First and Fifth Amendments of the Federal Constitution. Section 2(11) does not abridge the First Amendment in denying to an employee the right not to associate. $^{47}$ Freedom of assembly does not include the right to remain unorganized. ${ }^{48}$ Employment is a contractual relationship, and it has long been clear that freedom of contract is not absolute. ${ }^{49}$ There being no constitutional

81st Cong., 2d Sess. (1950) (between 75-80\% of railroad employees were union mémbers prior to enactment of $\S 2(11)$ in 1951) ; 96 Cong. Rec. 17050 (1951).

45. In passing $\S 2(11)$ of the RLA, Congress intended to eliminate "freeriders" who were deriving benefits from collective bargaining strength of unions but were contributing nothing to support unions financially. Hearings, supra note 3 , at $6,15-16,130$. Stability of income is essential to balance the equation between management and labor. See ColgatePalmolive-Peet Co. v. NLRB, 338 U.S. 355, 362-64 (1949) ; Williams v. Quill, 277 N.Y. 1, 9-10, 12 N.E.2d 547, 550-51 (1938) ; CIO, The Case Against "Rigrt to Work" Laws 145 (1955); Note, 40 Iowa L. Rev. 627, 636, 641 (1955).

46. Collection of funds for political purposes does not abridge free speech so long as unions do not represent that their political views are those of all their members. DeMille v. American Federation of Radio Artists, 31 Cal. 2d 139, 187 P.2d 769 (1947). But if a union does so represent, a contributing member having a contrary personal belief should be able to enjoin such a false representation or any attempt to discharge him for refusal to contribute, if the intent to represent is made known prior to collection of a political assessment. See ibid.

Several unions have endeavored to confine the imposition of dues, fees and assessments to a narrow concept of bargaining costs, disallowing political assessments. Hearings, supra note 3, at 33. The CIO-AFL merger agreement provides for a Civil Rights Committee, 78 Monthly LAB. REv. 1018 (1955), which might control political assessments.

Unlike the RLA, see note 1 supra, the Taft-Hartley Act, see note 5 supra, omits the term "assessments." Of course the scope of "dues" and "fees" is not standardized, and might be applied as broadly as "assessments." See Rosenthal, The National Labor Relations Act and Compulsory Unionism, 1954 WIs. L. Rev. 53, 71; Williams, supra note 19; 96 CoNG. REc. 17049-50 (1950).

47. U.S. CoNST. amend. I.

48. See AFL v. American Sash \& Door Co., 335 U.S. 538, 557, 559 (1949) (concurring opinion); Senn v. Tile Layers Protective Union, 301 U.S. 468, 480 (1937) ; DeMille v. American Federation of Radio Artists, 31 Cal. 2d 139, 154, 187 P.2d 769, 779 (1947).

Some doubt has been expressed as to whether freedom of association is part of the freedom of assembly protected by the First Amendment. See, generally, Abernathy, Right of Association, 6 S.C.L.Q. 32, 33-34, $49-59$ (1953). In Lincoln Federal Labor Union v. Northwestern Co., 335 U.S. 525, 531 (1949), the Court, in holding that union members have no constitutional right to require non-members to join their union, speaks of "participation in union assemblies" "to discuss and formulate plans," and not mere identification with a union through payment of dues, fees and assessments, which is the only degree of union affliation required by the RLA.

49. See West Coast Hotel Co. v. Parrish, 300 U.S. 379, 391 (1937). 
right involved, but rather a clash of interests between the organized and the unorganized, it is within the special province of the legislature to draw the line of desirable social policy, ${ }^{50}$ which it has done by enacting section $2(11)$. And even if compulsory membership does to some extent restrict freedom of assembly, the restriction is so slight as clearly to be outweighed by the benefits thought by Congress to inhere in union membership..$^{51}$ Section $2(11)$ curtails the freedom not to associate only to the extent of requiring identification with the union for purposes of collecting dues, fees and assessments, not in demanding active participation. ${ }^{52}$

Neither can it be said that section 2(11) infringes upon the employee's right to work. ${ }^{53}$ Historically, a right to work has denoted opportunity to follow a freely chosen occupation. ${ }^{54}$ The RLA has established safeguards against the infringement of this right by the employer or the union. Section 2(11) permits only a limited union shop. Racial and internal disciplinary policies of a union are prohibited grounds on which to base initiation or termination of employment. ${ }^{55}$ Indeed, the sole permissible basis for discharge from employment which may arise from union affiliation is failure to pay union dues, fees and assessments. ${ }^{56}$ Although the bargaining representative has authority to enter into a union shop trade agreement, the employees may discontinue the agreement. 57 The employer is free to choose from an unrestricted labor market. Other parts of the act augment the protections of section 2(11) by providing for administrative and judicial review of grievances. ${ }^{58}$

Unlike section $2(11)$, state right to work laws tend to upset the balance of power between management and labor by prohibiting unions from assuring

50. See AFL v. American Sash \& Door Co., 335 U.S. 538, 546 (1949).

51. See American Communications Ass'n v. Douds, 339 U.S. 382, $399-400$ (1950) : Virginian Ry. v. System Federation No. 40, 300 U.S. 515, 558 (1937).

52. See note 48 supra; cf. Rosenthal, supra note 46 , at 68 .

53. The right to work is protected by U.S. Const. amend. V. See Smith v. Texas, 233 U.S. 630, 636 (1914); Newman, The Closed Union and the Right to Work, 43 Colum. L. Rev. 42,43 (1943).

54. See Lenhoff, The Right To Work: Here And Abroad, 46 Ir.. L. Rev. 669 (1951),

55. See note 1 supra. As of 1950 , four national railroad unions were said to exclude negroes from membership due to provisions in the union constitution or bylaws. Such unions represent a quarter million employees. Hearings, supra note 3, at 24-25.

56. See note 1 supra.

57. 44 STAT. 582 (1926), as amended, 45 U.S.C. $\$ 156$ (1952). Cf. Labor Management Relations Act, $\$ 9$ (e) (1), 65 Stat. $601-02$ (1951), 29 U.S.C. $\$ 159$ (e) (1) (1952), amending 49 StAт. 45 (1935).

By analogy, the "contract bar" rule used by the NLRB would not prevent a "deauthorization" election under the RLA. The rule does not apply to union security agreements. See Great Atlantic \& Pac. Tea Co., 100 N.L.R.B. 1494 (1952).

58. 44 STAT. $577-78,580,582,585-86$ (1926), as amended, 45 U.S.C. $\$ \$ 152-53,155-57$, 159-60 (1952). It has been held that an employee need not exhaust all his remedies under the Act prior to initiating court action. Condol v. Baltimore \& O.R.R., 199 F.2d 400 (D.C. Cir. 1952). 
themselves of stability of income and membership. ${ }^{59}$ Moreover, evidence indicates that state right to work laws have made no positive contribution to the improvement of labor-management relations, the status of the worker, or the economic welfare of the states having such laws. ${ }^{60}$ The Railway Labor Act, through section $2(11)$, encourages a reasonable union security that is essential to union existence and improvement of labor standards. ${ }^{61}$

59. State right to work laws tend to impede the progress of employee interests by depriving unions of strength inherent in stable membership and income. This necessitates a greater degree of government regulation of labor-management relations, similar to European labor policy, but contrary to congressional intent and United States labor history. See J. I. Case Co. v. NLRB, 321 U.S. 332, 335 (1944); CIO, op. cit. supra note 45; Jensen, Notes on the Beginnings of Collective Bargaining, 9 IND. \& LAB. REL. REv. 225 (1956) ; Lenhoff, supra note 54; Taylor, Has Collective Bargaining Failed?, 248 Annals 154 (1946) ; Harv. L. Sch. Rec. No. 9, Nov. 24, 1954, p. 1, col. 2, p. 4, col. 2.

60. See CIO, op. cit. supra note 45, at 161; Cheit, Union Security and the Right to Work, 6 LAB. L.J. 357 (1955) ; Kuhlman, Right to Work Lawes: The Virginia Experience, 6 LAB. L.J. 453 (1955); Levinson, Union Shop Under the Railway Labor Act, 6 LAB. L.J. 441 (1955) ; Meyers, Effects of "Right-to-Work" Lawe: A Study of the Texas Act, 9 IND. \& LAB. REL. REv. 77 (1955); Taylor, supra note 59.

61. See note 59 supra; Branders, The Curse of Bigness 93 (1934). 